\title{
Peningkatan Gizi Protein Hewani Melalui Keterampilan Pembuatan Bakso Ikan kepada Masyarakat Desa Tunggilis dan Banjarharja, Kabupaten Pangandaran
}

\section{Increasing Animal Protein Through Fish Meatball Making Skills to the Society of Tunggilis and Banjarharja Villages, Pangandaran Regency}

\author{
Junianto $^{1}$, Izza Mahdiana Apriliani ${ }^{1}$, Lantun Paradhita Dewanti ${ }^{1}$, Irfan Zidni ${ }^{1}$
}

* Korespondensi Penulis:

\section{Izza Mahdiana Apriliani \\ E-mail: \\ izza.mahdiana@unpad.ac.id}

${ }^{1}$ Departemen Perikanan, Fakultas Perikanan dan Ilmu Kelautan, Universisitas Padjadjaran, Sumedang

Submitted July 29, 2020.

Revised Aug 4, 2020.

Accepted Aug 25, 2020.

\section{Abstract}

Fish is a type of healthy food that is low in saturated fat and high in protein and has omega-3 content. Consumption of protein is one of the factors that directly influences one's nutrition. Pangandaran Regency has the potential to develop in the field of fisheries. But there are still problems regarding the declining quality of community nutrition. To support the improvement of community nutrition and fish product development in Pangandaran Regency based on its potential, namely through efforts to increase understanding and knowledge in food production by carrying out training / workshops for the manufacture of processed fishery products in the form of fish baso. The stages of the implementation of the activities that have been carried out consist of the socialization and initiation stages, the counseling and training stages (the importance of consuming fish; fond of eating fish campaigns to improve community nutrition; The delivery method is in the form of lecture, discussion and demonstration methods. The results of this training activity showed that the target audience understood the importance of protein nutrition sourced from fish. As well as an increase in the skills of the target audience in processing diversified products from fish-based ingredients in the form of meatballs.

Keywords: fish meatball, diversification, fisheries product, skills, socialization

\section{Abstrak}

Ikan merupakan jenis makanan sehat yang rendah lemak jenuh dan tinggi protein serta memiliki kandungan omega 3. Konsumsi jenis protein salah satu faktor yang secara langsung berpengaruh terhadap gizi seseorang. Kabupaten Pangandaran memiliki potensi untuk berkembang dalam bidang perikanan. Namun masih terjadi permasalahan mengenai kualitas gizi masyarakat yang menurun. Untuk mendukung peningkatan gizi masyarakat dan pengembangan produk ikan di Kabupaten Pangandaran berdasarkan potensi yang dimilikinya yaitu melalui upaya peningkatan pemahaman dan pengetahuan dalam produksi pangan yaitu dengan melaksanakan kegiatan pelatihan/workshop pembuatan produk olahan hasil perikanan berupa baso ikan. Tahapan pelaksanaan kegiatan yang telah dilakukan terdiri dari tahap sosialisasi dan inisiasi, tahap penyuluhan dan pelatihan (pentingnya mengkonsumsi ikan; kampanye gemar makan ikan untuk peningkatan gizi masyarakat; serta pelatihan dan demonstrasi pembuatan produk berupa bakso ikan), dan tahap terakhir adalah tahap evaluasi kegiatan. Metode penyampaian berupa metode ceramah, diskusi dan demonstrasi. Hasil kegiatan pelatihan ini menunjukkan bahwa khalayak sasaran memahami pentingnya gizi protein yang bersumber dari ikan. Serta adanya peningkatan kemampuan khalayak sasaran dalan pengolahan diversifikasi produk dari bahan dasar ikan berupa bakso.

Kata Kunci: bakso ikan, diversifikasi, produk perikanan, skill, sosialisasi

\section{Pendahuluan}

Dibandingkan dengan nilai gizi daging hewan darat, misalnya daging 
sapi, kedudukan ikan dapat dikatakan jauh lebih tinggi (Apasha et al., 2015). Ikan juga merupakan bahan pangan yang memiliki nilai gizi yang tinggi karena berperan sebagai sumber protein, lemak, karbohidrat, vitamin dan mineral (Afrianto dan Liviawaty, 1989). Komposisi kimia daging ikan umumnya terdiri dari 70-85 \% kadar air, 15-25 $\%$ protein, 1-10 \% kadar lemak, 0,1-1 \% karbohidrat, dan 1-15\% mineral (Okada 1990).

Ikan merupakan jenis makanan sehat yang rendah lemak jenuh dan tinggi protein serta memiliki kandungan omega 3 (Sukarsa 2004). Konsumsi jenis protein salah satu faktor yang secara langsung berpengaruh terhadap gizi seseorang. Hal itu akan mempengaruhi kualitas sumberdaya di masa yang akan datang. Pada umur balita protein sangat dibutuhkan untuk pertumbuhan tubuh dan perkembangan otak. Untuk memenuhi hal tersebut salah satunya dengan mengkonsumsi sumber protein hewani yaitu ikan.

Kabupaten Pangandaran memiliki potensi untuk berkembang dalam bidang perikanan. Namun masih terjadi permasalahan mengenai kualitas gizi masyarakat yang menurun. Berdasarkan pantauan Dinas Kesehatan Pangandaran setidaknya jumlah balita yang menderita kekurangan gizi dapat mencapai 41 anak di tahun 2015 dan meningkat menjadi 48 anak di tahun 2016. Dengan demikian sangat beralasan dengan mendukung program pemerintah dengan gerakan makan ikan. Salah satu upaya dalam menjalan program gerakan makan ikan yaitu melalui proses pengolahan pangan berbahan baku ikan. Pengolahan hasil perikanan terdiri dari pengolahan tradisional dan modern. Pada umumnya pengolahan tradisional masih bersifat sederhana, dilakukan oleh nelayan dan keluarganya di sepanjang pantai tempat pendaratan ikan. Produk olahan akan lebih meningkatkan konsumsi masyarakat terhadap ikan, karena lebih praktis dan mudah disajikan. Produk perikanan juga salah satu upaya dalam meningkatkan nilai tambah (Purwaningsih 2015).

Pengembangan berbagai produk olahan hasil perikanan dapat dijadikan alternatif menumbuhkan kebiasaan mengkonsumsi ikan bagi masyarakat Indonesia, sekaligus merupakan upaya untuk meningkatkan nilai gizi masyarakat. Salah satu bentuk dari produk olahan ikan tersebut adalah bakso ikan. Bakso merupakan produk olahan dari daging yang cukup digemari masyarakat. Pada umumnya bakso dibuat dari daging sapi namun sudah banyak dijumpai dipasaran bakso dibuat dari daging ikan.
Hampir semua jenis ikan dapat dimanfaatkan sebagai bahan pembuatan bakso dengan cara pengolahan yang tepat. Untuk mendukung peningkatan gizi masyarakat dan pengembangan produk ikan di Kabupaten Pangandaran serta berdasarkan potensi yang dimilikinya yaitu melalui upaya peningkatan pemahaman dan pengetahuan dalam produksi pangan yaitu dengan melaksanakan kegiatan pelatihan/workshop pembuatan produk olahan hasil perikanan berupa bakso ikan. Kegiatan tersebut harapannya dapat menunjang peningkatan gizi masyarakat, pengembangan produk disertai dengan peiningkatan pendapatan masyarakat.

\section{Materi dan Metode Pelaksanaan}

Penyampaian informasi yang tepat, jelas dan menarik dapat mempengaruhi terserapnya informasi pada khalayak sasaran (Tindaon 2018). Adanya pemberihan informasi yang dilakukan pada masyarakat desa Banjarharja dan Tunggilis adalah salah satu cara untuk memberitahukan kepada masyarakat pentingnya konsumsi ikan untuk memenuhi kebutuhan gizi masyarakat. Masyarakat dapat lebih mengenal jenis kebutuhan gizi yang diperlukan tubuh melalui konsumsi ikan.

Penyampaian pentingnya konsumsi ikan sifatnya persuasif, artinya bahwa mengajak masyarakat khususnya ibu-ibu untuk mengolah lauk pauk dengan tambahan dari olahan ikan. Salah satu bentuk olahan ikan yang sederhana adalah bakso ikan. Bakso ikan ini dapat diaplikasikan dalam kehidupan sehari-hari dengan olahan skala rumah tangga. Realisasi dari kegiatan tersebut dilihat dari indikator keberhasilan program, dapat dilihat pada Tabel 1.

Kegiatan pelatihan olahan bakso ikan secara keseluruhan dilaksanakan pada Januari-April 2017. Pelaksanaan terdiri dari 3 tahap yaitu tahap inisiasi dan sosialisasi, tahap pelaksanaan pelatihan serta tahap evaluasi. Tahap pertama yaitu inisiasi dan sosialisasi, tahapan ini diawali dengan mengidentifikasi potensi perikanan yang ada di dua desa tersebut serta perijinan kepada Kepala Desa Banjarharja dan Tunggilis sebagai sasaran terselenggaranya kegiatan ini. Kegiatan berikutnya dari tahapan sosialisasi ini adalah audensi dengan khalayak sasaran. Khalayak sasaran untuk kegiatan ini adalah ibu-ibu rumah tangga yang tergabung dalam organisasi Pemberdayaan Kesejahteraan Keluarga (PKK). Tahapan kedua yaitu pelaksanaan pelatihan dengan metode ceramah, diskusi dan 
demonstrasi.

Tabel 1 Indikator keberhasilan program

\begin{tabular}{clll}
\hline No. & \multicolumn{1}{c}{ Indikator pencapaian } & \multicolumn{1}{c}{$\begin{array}{c}\text { Base line } \\
\text { (Sebelum kegiatan) }\end{array}$} & Harapan setelah kegiatan \\
\hline 1. & $\begin{array}{l}\text { Pemahaman mengenai } \\
\text { pentingnya mengkonsumsi }\end{array}$ & $\begin{array}{l}\text { Tidak memiliki ketertarikan } \\
\text { terhadap konsumsi ikan }\end{array}$ & $\begin{array}{l}\text { Ada pemahaman mengenai } \\
\text { mengkonsumsi ikan untuk } \\
\text { peningkatan gizi anak }\end{array}$ \\
$\begin{array}{l}\text { ikan } \\
\begin{array}{l}\text { Pemahaman mengenai } \\
\text { diversifikasi produk } \\
\text { olahan ikan salah satunya } \\
\text { bakso ikan dan cara } \\
\text { membuatnya }\end{array}\end{array}$ & $\begin{array}{l}\text { Mengetahui adanya bakso ikan } \\
\text { namun tidak memahami cara } \\
\text { pengolahan bakso ikan }\end{array}$ & $\begin{array}{l}\text { Ada pemahaman mengenai } \\
\text { pengolahan bakso ikan }\end{array}$ \\
\hline
\end{tabular}

Khalayak sasaran akan diberikan pengetahuan dengan cara penyuluhan tentang (1) pentingnya mengkonsumsi ikan sekaligus kampanye gemar makan ikan untuk peningkatan gizi masyarakat serta (2) pengetahuan diversifikasi produk olahan perikanan berbasis sumberdaya lokal. Diversifikasi produk dilakukan melalui pelatihan dan demonstrasi pembuatan produk berupa bakso ikan. Kegiatan ini merupakan kegiatan belajar sekaligus mempraktekkannya (learning by doing). Hasil dari kegiatan ini diharpkan membawa perubahan dalam hal pengetahuan (knowledge), cara berfikir (thinking), kecakapan (skill) dan sikap. Sehingga capaian yang diharapkan dari penyuluhan terpenuhi. Tahapan ketiga yaitu tahap evaluasi kegiatan yang telah dilaksanakan kepada khalayak sasaran. Evaluasi dilakukan untuk mengetahui tingkat keberhasilan program. Cara penilaian pada tahap ini melalui wawancara dan pemantauan selama kegiatan berlangsung.

\section{Hasil dan Pembahasan}

Pelaksanaan kegiatan diawali dengan tahap sosialisasi dan inisiasi kepada khalayak sasaran. Tahap ini mendapatkan hasil positif oleh Kepala Desa Banjarharja dan Tunggilis dengan mendukung dan mengijinkan untuk dilakukannya kegiatan ini. Salah satu bentuk dukungan yang diberikan oleh kepala desa adalah diperbolehkannya balai desa digunakan sebagai tempat pertemuan dengan untuk penyampaian materi dalam kegiatan ini.

Kegiatan berikutnya dari tahapan sosialisasi dan inisiasi adalah audensi dengan khalayak sasaran. Khalayak sasaran untuk kegiatan ini adalah ibu-ibu rumah tangga yang tergabung dalam organisasi PKK. Ibu-ibu diinformasikan bahwa kegiatan telah direncanakan akan segera dimulai. Pertemuan dengan khalayak sasaran membahas tahapantahapan kegiatan baik terkait dengan waktu dan cakupan materi kegiatan.

Kegiatan pelatihan diawali dengan pre-test tentang pengetahuan protein ikan dan pengolahan bakso ikan. Pelatihan diawali dengan penyampaian materi pentingnya mengkonsumsi ikan sekaligus kampanye gemar makan ikan untuk peningkatan gizi masyarakat. Ceramah atau seminar merupakan proses introduksi pengetahuan dari pemberi ceramah kepada khalayak sasaran (Apriliani et al. 2017). Pengetahuan yang disampaikan dalam kasus ini adalah pentingnya mengkonsumsi ikan, kampanye gemar makan ikan untuk peningkatan gizi masyarakat serta diversifikasi produk olahan perikanan berbasis sumberdaya lokal. Pemberi ceramah adalah berasal dari kegiatan Pengabdian Kepada Masyarakat (PKM) Fakultas Perikanan dan Ilmu Kelautan Universitas Padjadjaran. Khalayak sasarannya adalah ibu-ibu rumah tangga yang bergabung dalam organisasi PKK yang ada di Desa Banjarharja dan Tunggilis Kecamatan Kalipucang Kabupaten Pangandaran.

Kegiatan pelatihan ini diikuti oleh 42 orang dari Desa Tunggilis dan Banjarharja. Materi yang disampaikan adalah pentingnya mengkonsumsi ikan sekaligus kampanye gemar makan ikan untuk peningkatan gizi masyarakat. Suasana saat penyampaian materi berlangsung dalam suasana keakraban dan kekeluargaan. Bahasa yang digunakan dalam penyampaian materi menggunakan campuran antara bahasa Sunda dan bahasa Indonesia. Selain itu kata-kata jenaka sering kali dilontarkan untuk menghangatkan suasana. Penggunaan kedua bahasa ini dimaksudkan agar pesan yang hendak disampaikan efektif dan efisien. 
Suasana keakraban tetap terjaga selama penyampaian materi tersebut berlangsung sebagaimana terlihat pada Gambar 1.

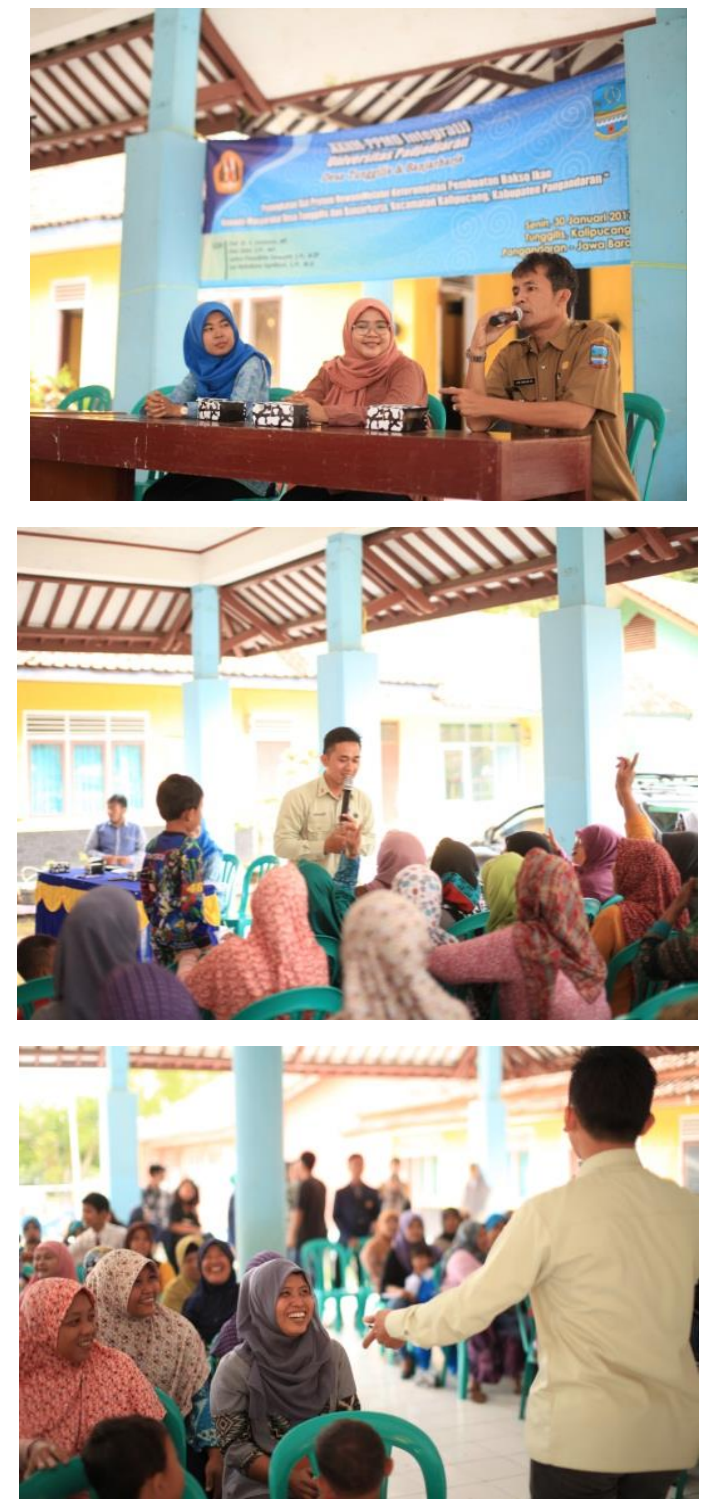

Gambar 1 Penyampaian materi pentingnya konsumsi ikan

Khalayak sasaran setelah mendapatkan pengetahuan tentang pentingnya konsumsi ikan, maka selanjutnya perlu untuk mendapatkan pelatihan salah satu produk olahan yang berbahan baku ikan. Kegiatan pelatihan ini dimaksudkan untuk mengaplikasikan pengetahuan tentang pembuatan baso ikan tersebut dalam bentuk skill atau keterampilan. Keterampilan yang dimiliki khalayak sasaran menunjukkan kompetensinya karena kompetensi itu tidak hanya kemampuan untuk mengetahui tetapi juga kecakapan untuk mengerjakannya.

Pemateri tidak banyak mengalami kesulitan dalam memberikan petunjuk-petunjuk dalam pembuatan baso ikan. Beberapa pekerjaan dalam pembuatan bakso ikan seperti penyiapan bumbu, pencampuran bumbu dengan ikan dan pengukusan dengan mudah dilakukan oleh peserta yang disajikan pada Gambar 2. Pemateri tidak banyak mengalami kesulitan dalam melatih keterampilan peserta untuk melakukan pengerjaan dalam pembuatan baso ikan.
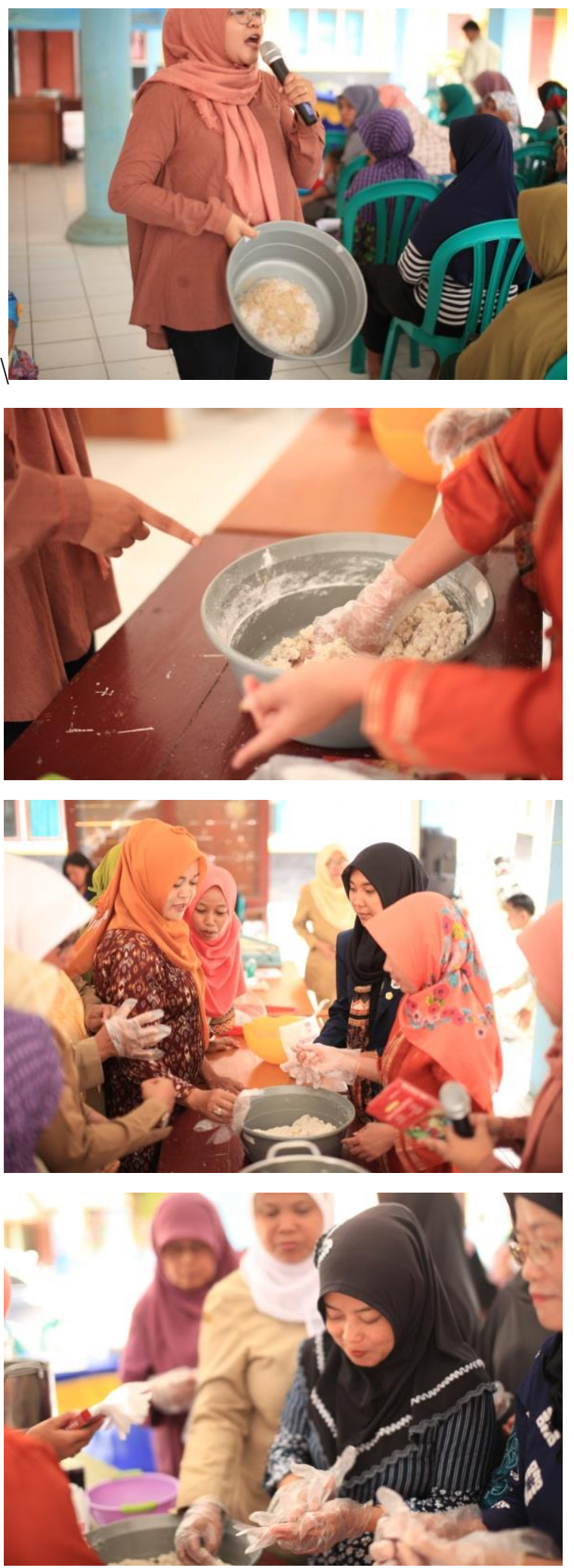

Gambar 2 Pelatihan pembuatan baso ikan 
Tabel 1 Indikator pelaksanaan program

\begin{tabular}{|c|c|c|c|}
\hline No. & Indikator pencapaian & $\begin{array}{c}\text { Base line } \\
\text { (Sebelum kegiatan) }\end{array}$ & $\begin{array}{c}\text { Pencapaian } \\
\text { setelah kegiatan }\end{array}$ \\
\hline
\end{tabular}

2. Pemahaman mengenai diversifikasi produk olahan ikan salah satunya bakso ikan dan cara membuatnya :
a. Tingkat pengetahuan diversifikasi produk ikan
b. Tingkat pengetahuan dan skills jenis olahan ikan
c. Tingkat keterampilan pembuatan bakso ikan
- Belum mengetahui - Paham
- Sebagian belum - Terampil mengetahui
- Belum mengetahui - Terampil

Akhir dari kegiatan penyampaian materi maupun pelatihan pembuatan bakso ikan adalah diskusi. Diskusi dimaksudkan untuk lebih mempertajam pesan yang telah disampaikan saat ceramah/penyampaian materi. Berbagai pertanyaan dan pendapat dilontarkan oleh para peserta sehingga suasana pertemuan terasa akrab dengan semangat kekeluargaan. Banyaknya pertanyaan dan lontaran pendapat tersebut menunjukkan bahwa materi yang disampaikan dapat dikatakan telah tersampaikan kepada objek sasasaran dengan baik.

Beberapa faktor yang mempengaruhi keberhasilan ini antara lain tingkat pendidikan objek sasaran. Para peserta berpendidikan SLTA, dan ada juga yang lulusan paket C. Selain itu pendukung lainnya adalah keinginan peserta yang sangat kuat untuk menerima materi yang disampaikan oleh tim. Semangat dari khalayak sasaran ini merupakan modal utama yang harus tetap terjaga agar supaya kegiatan-kegiatan berikutnya dapat berjalan dengan baik dan mendapatkan hasil yang optimal.

Fakta yang sangat menarik dalam diskusi tersebut adalah pemberi materi menempatkan dirinya sebagai bagian dari kelompok masyarakat sehingga para peserta menjadi terbuka dalam mengemukakan permasalahan dan pandangannya. Menurut Adimihardja dan Hikmat (2003), teknik penyampaian tersebut merupakan salah satu metode Participatory Research Apprasial. Dalam hal ini, pemateri berusaha menempatkan posisi sebagai insider. Pada akhir diskusi, umumnya para peserta menyadari dan memahami tentang pentingnya konsumsi ikan untuk memenuhi kebutuhan gizi dalam kehidupan sehari-hari.

Kemudahan pemateri dalam pelatihan pembuatan bakso ikan disebabkan beberapa faktor pendukung. Pertama, pengerjaan atau operasi dalam pembuatan baso ikan seperti penyediaan bumbu, pengukusan dan lain-lain merupakan kegiatan yang sehari-hari dilakukan oleh peserta. Kedua, alat-alat yang digunakan untuk unit operasi proses dalam pembuatan baso ikan adalah sederhana dan peserta telah mengenal sebelumnya. Faktor pendukung lain adalah partisipasi aktif peserta, hal ini terlihat dengan penyediaan tempat untuk pelatihan yang disediakan. Akhir dari kegiatan pelatihan ini tidak ada hambatan yang berarti dan dapat dikatakan berhasil. Pelatihan menjadi indikator bahwa materi dan ketrampilan yang didapatkan telah memberi manfaat dalam menambah dan memperluas wawasan pengetahuan (Astuti et al. 2018).

Secara umum kegiatan peningkatan gizi protein hewani melalui keterampilan pembuatan bakso ikan kepada masyarakat Desa Tunggilis dan Banjarharja, Kabupaten Pangandaran berjalan dengan lancar. Berdasarkan Tabel 2 menunjukkan perubahan sudut pandang khalayak sasaran mengenai pentingnya konsumsi ikan serta adanya peningkatan skill dalam pembuatan bakso ikan.

\section{Kesimpulan}

Berdasarkan kegiatan pelatihan secara keseluruhan, baik dalam bentuk ceramah/diskusi maupun pelatihan pembuatan bakso ikan disimpulkan bahwa khalayak sasaran memahami pentingnya gizi protein yang bersumber dari ikan. Serta adanya peningkatan kemampuan khalayak sasaran dalan pengolahan diversifikasi produk dari 
bahan dasar ikan berupa bakso.

\section{Ucapan Terimakasih}

Penulis mengucapkan terima kasih kepada Direktorat Riset, Pengabdian Pada Masyarakat dan Inovasi Universitas Padjadjaran yang telah memberikan dana hibah Pengabdian Pada Masyarakat tahun anggaran 2017. Ucapan terimakasih juga disampaikan kepada Kepala Desa Tunggilis dan Banjarharja serta kelompok PKK yang telah antusias dalam pelaksanaan kegiatan ini sehingga pengabdian ini berjalan dengan baik.

\section{Daftar Pustaka}

Adimihardja K dan Hikmat H. 2003. Participatory Research Appraisal: dalam Pelaksanaan Pengabdian kepada Masyarakat. Bandung (ID): Humaniora.

Afrianto E dan Liviawaty E. 1989. Pengawetan dan Pengolahan Ikan. Jakarta (ID): Kanisius.

Apasha SR, Yanti ND, dan Rifiana. 2015. Preferensi Konsumen Terhadap Ikan Tawar dan Ikan Laut di Pasar Tradisional Bauntung Kota Banjarbaru. Jurnal Agrides 5 (1): 89-104.

Apriliani IM, Purba NP, Dewanti LP, Herawati H, Faizal I. 2017. Aksi Bersih Pantai dalam Rangka Penanggulangan Pencemaran Pesisir di Pantai Pangandaran. Jurnal Pengabdian Kepada Masyarakat 1 (2): 77-80.

Astuti S, Suharyono, dan Affandi MI. 2018. Pelatihan Pembuatan Bakso Ikan yang Diperkaya Jamur Tiram dan Analisis Usaha pada Usaha Mikro Olahan Ikan di Kelurahan Kangkung Kecamatan Bumi Waras Kota Bandar Lampung. [internet]. [dapat diunduh di http://repository.lppm.unila.ac.id/9686/].

Dinas Kesehatan Kabupaten Pangandaran. Data Kesehatan Tahun 2016. Pangandaran (ID): Dinas Kesehatan Kabupaten Pangandaran.

Okada M. 1990. Fish as Raw Material Fishery Products. Dalam Motohiro T, Kadota H, Hashimoto, Kayama $\mathrm{M}$ and Tokunaga $\mathrm{T}$ (Eds): Science of Processing Marine Food Product. Japan (JP): Internastional Agency.

Purwaningsih E. 2015. Analisis Nilai Tambah Produk Perikanan Lemuru Pelabuhan Muncar Banyuwangi. Jurnal Ilmiah Teknik Industri 14 (1): 13-23.
Sukarsa DR. 2004. Studi Aktivitas Asam Lemak Omega3 Ikan Laut pada Mencit Sebagai Model Hewan Percobaan. Buletin Teknologi Hasil Perikanan 7 (1): 68-79.

Tindaon RL. 2018. Pengaruh Komunikasi, Informasi, dan Edukasi (Kie) Melalui Media Leaflet dan Video terhadap Pengetahuan dan Sikap Remaja tentang Paparan Pornografi di SMP Negeri 1 Sidamanik Kec. Sidamanik Kab. Simalungun Tahun 2016. Jurnal Ilmiah Penelitian Kesehatan 3 (1): 44-64. 